\title{
Bark Harvesting Systems of Drimys brasiliensis Miers in the Brazilian Atlantic Rainforest
}

\author{
ALEXANDRE MARIOT ${ }^{1}$, ADELAR MANTOVANI ${ }^{2}$ and MAURÍCIO S. DOS REIS ${ }^{1}$ \\ ${ }^{1}$ Núcleo de Pesquisas em Florestas Tropicais, Universidade Federal de Santa Catarina, Centro de Ciências Agrárias, \\ Departamento de Fitotecnia, Rodovia Admar Gonzaga, 1346, 88034-001 Florianópolis, SC, Brasil \\ ${ }^{2}$ Universidade do Estado de Santa Catarina, Centro Agroveterinário, \\ Departamento de Engenharia Florestal, Av. Luiz de Camões, 2090, 88520-000 Lages, SC, Brasil
}

Manuscript received on May 3, 2013; accepted for publication on October 28, 2013

\begin{abstract}
Drimys brasiliensis Miers, locally known as cataia or casca-de-anta, is a native tree species of the Atlantic Rainforest. Its bark is harvested from natural populations. This study examined the recovery capacity of the bark of $D$. brasiliensis under different bark harvesting methods, as well as the influence of these approaches on its population dynamics and reproductive biology. While none of these treatments resulted in changes in phenological behavior or the rate of increase of diameter at breast height and tree height, the removal of wider bark strips resulted in lower rates of bark recovery and higher rates of insect attack and diseases. Accordingly, the results recommend using strips of bark $2 \mathrm{~cm}$ wide and $2 \mathrm{~m}$ long, with $4 \mathrm{~cm}$ between strips, for effective rates of bark regrowth and for lower susceptibility to insect attack and diseases. From these studies, we concluded that $D$. brasiliensis has a high potential for sustainable management of its natural populations, demonstrating the possibility of generating an important supplementary income for farmers and contributing to the use and conservation of the Atlantic Rainforest.
\end{abstract}

Key words: bark harvesting, medicinal plant, sustainable management, Drimys brasiliensis, insect attack.

\section{INTRODUCTION}

The commercial use of products derived from plants is growing in the world, increasing the intensity and frequency of medicinal plant harvesting from wild habitats, despite the very limited cultivation of wild medicinal plants. The wild harvesting of medicinal plants from forest ecosystems represents an important source of income worldwide, although such harvesting affects ecological processes at different levels, from individual plants, to populations, and even ecosystems (Reis et al. 2003, Ticktin 2004, Shanley et al. 2006).

Correspondence to: Alexandre Mariot

E-mail: alexandre_mariot@yahoo.com.br
Different kinds of wild plants (epiphytes, herbs, lianas and trees) and different parts of plants (such as roots, bark, leaves, flowers and fruits) are used in folk medicine (Geldenhuys and Mitchel 2006). The effect of harvesting on these plants varies according to what part of the plant is used, as well as the frequency and intensity of harvest. Additionally, the harvest can change the survival, growth and reproduction of the harvested individuals (Hall and Bawa 1993, Reis et al. 2003, Ticktin 2004).

Harvesting flowers and fruits clearly has far less impact than the damage caused by harvesting 
bark or roots, or by removing of the whole plant (Cunningham 2001). Bark regrowth varies between species and for some species, it does not recover; causing the death of these plants in many cases (Delvaux et al. 2009, Geldenhuys et al. 2007, Vermeulen 2007). If the thin layer of cambium cells in the inner bark is removed during the harvest, there can be significant interruption in the transport of water and nutrients to and from the roots and leaves, as well as significant damage to the natural protection against attack by herbivores, insects, fire and fungi, since these cambium cells surround the xylem. Additionally, it can cause plant death, reducing the density of exploited species, and consequently reduced seed production and gene flow, as seen in Prunus africana (Cunningham and Mbenkim 1993). Guedje et al. (2007) observed that for Garcinia lucida the bark harvesting strategies currently undertaken are causing plant mortality resulting in decreased density of the species, showing that the harvest strategy being used is not sustainable.

In this context, the sustainable management concept proposed by Fantini et al. (1992) and applied to the heart-of-palm - Euterpe edulis (Reis et al. 2000a, b, Conte et al. 2008, Silva and Reis 2010), pariparoba - Piper cernuum (Mariot et al. 2002, 2003, 2007), espinheira-santa - Maytenus ilicifolia (Steenbock et al. 2003, Steenbock and Reis 2004), caraguatá - Bromelia anthiacantha (Duarte et al. 2007, Filippon et al. in press) and leather-leaf fern - Rumohra adiantiformis (Baldauf et al. 2007, Baldauf and Reis 2010), could be a sustainable alternative.

The sustainable management system proposed in Fantini et al. (1992) is based on two aspects: cyclical harvesting and ecological knowledge of each species. Thus, in order to guarantee cyclical harvesting, aspects of demography and reproductive biology should be observed. The assessment of current biomass and growth indexes, as well as the natural regeneration dynamics and the number of reproductive individuals to maintain the original population structure (demographically and genetically) is essential (Reis 1996, Reis et al. 2003). For this type of management a dynamic approach is necessary, based on the autoecology of each harvested species, considering the species in the forest environment (Mariot and Reis 2006).

The system also considers the part of the plant used. For medicinal plants, if leaves are used, the assessment of recovery can be number of leaves or number of branches; if roots are used, the assessment can be the diameter of roots (Reis 1996, Reis et al. 2003, Mariot and Reis 2006). If the part used is the bark, the assessment of bark recovery can be measured from the exposed area after harvesting.

The bark harvesting practice can be sustainable if the species population structure can be maintained under harvesting, allowing for natural regeneration. This ensures ecosystem sustainability through diversity preservation (Reis et al. 2003). Other non-timber forest products, like fruits, seeds, ornamental plants and honey, can provide an important supplementary income for forest owners. Equilibrium between market demands and recovery capacity after harvesting is necessary for the sustainable harvesting of medicinal plants.

This study examined the bark recovery capacity of Drimys brasiliensis Miers under different methodologies of bark harvesting, and the influence of these methods on its population dynamics and reproductive biology.

D. brasiliensis Miers, locally known as cataia or casca-de-anta, is a native tree of the Araucaria Forest, an Atlantic Rainforest ecosystem. Its bark has been used for folk medicine to treat scurvy, fever, stomach aches, also as an aromatic for culinary use (Trinta and Santos 1997). Malheiros et al. (2005) detected antifungal activity of sesquiterpenes found in the bark of D. brasiliensis, and CechinelFilho et al. (1998) isolated and identified several active compounds from its bark, and found that the polygodial was more potent in controlling pain. 
Ribeiro et al. (2008) identified that the essential oils found in the leaves and bark of $D$. brasiliensis were lethal to dog and cattle ticks.

Studies conducted in different environments, such as the understory of Araucaria angustifolia plantations and in a primary Araucaria Forest, found a stem density of 105 and 31 (for DBH $>5 \mathrm{~cm}$ ) respectively for $D$. brasiliensis with an inverse J-shaped size class distribution (Mariot et al. 2010). In the study conducted in the primary Araucaria Forest the authors found a strong spatial structure. However, there are no sustainable criteria of this harvesting process in natural populations, which is the only source for obtaining barks for this not domesticated species.

\section{MATERIALS AND METHODS}

\section{STUDY AREAS}

The studies were carried out in two natural populations of Drimys brasiliensis, $10 \mathrm{~km}$ apart: The Caçador National Forest (CNF) $\left(26^{\circ} 45^{\prime} 50,24^{\prime \prime}\right.$; $\left.51^{\circ} 11^{\prime} 59,30^{\prime \prime} \mathrm{W}\right)$ and in a forest fragment (FF) (26 $\left.45^{\prime} 20,44^{\prime \prime} \mathrm{S} ; 51^{\circ} 05^{\prime} 46,77^{\prime \prime} \mathrm{W}\right)$ on a small farm, located in the Araucaria Forest, Atlantic Rainforest domain. According to the Koeppen classification, the climate of the region is humid subtropical, with an annual rainfall of $1700 \mathrm{~mm}$ and average annual temperature of $17^{\circ} \mathrm{C}$. The CNF study area presents a natural population under an Araucaria angustifolia plantation established in 1958, and the FF study area is used for cattle farming and harvesting of non-timber forest products such as firewood and seed, honey production, and the exploitation of Ilex paraguariensis for tea. Demographic aspects of this area can be found in Mariot et al. (2010).

\section{HARVEST TREATMENTS AND ASSESSMENTS}

Two experiments of $D$. brasiliensis bark harvesting were conducted to determine the best combination factors (harvest prescriptions) for bark recovery, without affecting growth and plant development.
In the first experiment, installed in April 2004, the length of the strip was 1 meter, three sources of variation: factor one - season (autumn or spring), factor two - percent of $\mathrm{CBH}$ (circumference at breast height) $(20,30$ or $40 \%)$, and factor three - number of strips (1, 2 or 3$)$, resulting in 18 combinations (2 seasons $\mathrm{x} 3$ percentages of CBH x 3 number of strips).

A second experiment was started in October 2004 with strips with a fixed width of 2 centimeters, and 2 sources of variation: factor one - distance between strips ( 4 or 8 centimeters), and factor two strips with different lengths ( 1 or 2 meters), resulting in 4 combinations ( 2 distances between strips $\mathrm{x} 2$ strip lengths). Bark was harvested using a knife.

The two experiments were conducted in randomized complete blocks. Experiment one included three-factors with six replications (blocks) (45 trees in total), and experiment two included a two-factor with four replications (16 trees in total). In both experiments the block was used as a function of the stem diameter and spatial location of the plants (CNF or FF), resulting in all combinations in all places and classes of $\mathrm{CBH}$. In experiment one, four blocks were installed in the $\mathrm{CNF}$ and two repetitions in the FF, while all the blocks of experiment two were installed in the FF. For comparisons of growth and plant development between harvested and non-harvested plants, 225 trees were used as a control.

The individuals used in the experiments had a diameter at breast height of $(\mathrm{DBH})>5 \mathrm{~cm}$, with a mean DBH of $9.7 \mathrm{~cm}(2.8 \mathrm{~cm}$ standard deviation) and a mean height of $7 \mathrm{~m}(2.4 \mathrm{~m}$ standard deviation). Evaluations were carried out annually from 2005-2008, and the percentage of bark regrowth was estimated by using a ruler to measure the regeneration of the bark, and by comparing the harvested wounds on the stems with the wound area at the time of harvest. For example, in experiment one with a fixed strip of 1 meter, for a trunk of $10 \mathrm{~cm}$ of $\mathrm{CBH}$, the combination of $30 \%$ of $\mathrm{CBH}$ and 1 strip, resulted in a strip of 3 
$\mathrm{cm}$ of width and an area of $300 \mathrm{~cm}^{2}$ at the moment of harvest. $30 \%$ of $\mathrm{CBH}$ and 2 strips resulted in 2 strips of $1.5 \mathrm{~cm}$ each. All data were transformed by $\sqrt{ } \mathrm{x}$ to standardize variances and an Analysis of Variance (ANOVA) test was conducted. A Tukey Test was used in the separation of averages for the percentage of recovery for all factors and years analyzed. In all experiments the exploited bark was weighed on electronic scales, and chopped and dried separately. A wood stove installed in the CNF was used to dry the bark. After drying, the bark was weighed again and a comparison between dry and fresh weight was estimated.

For experiment one the percentage of the wound of harvested plants which was exposed to attacks from insects and diseases in 2008 was related to the increase in $\mathrm{DBH}$, total height and standard phenology (Fournier 1974). A Dunn test (Zar 1999) was used to compare the percentage of wound area with insect and disease incidence, to factor 2 (percentage of $\mathrm{CBH}$ ), factor 3 (number of strips), DBH increments, total height, and phenophases. In experiment two, the percentage of the wound area in harvested plants in 2008 was compared to the intensity of insect and disease attack.
EVALUATION OF DEMOGRAPHIC STRUCTURE

Based on Mariot et al. (2010), data for comparisons of bark productivity between $\mathrm{CNF}$ and Caçador Genetic Forest Reserve (FGPC) (26 51'0,81'S; $50^{\circ} 57^{\prime} 58,12^{\prime \prime} \mathrm{W}$ ), an area of primary forest in the Araucaria Forest, were used. One Plot of 1 hectare in both CNF and FGPC was created and evaluated, considering all $D$. brasiliensis plants within the plot.

\section{RESULTS AND DISCUSSION}

EXPERIMENT 1

The ANOVA test results of experiment one are presented in Table I. The use of randomized blocks was efficient for annual evaluations, and significant differences were found between levels of the three factors studied every year (factor 1 season; factor 2 - \% $\mathrm{CBH}$; factor 3 - number of strips), and for the interaction between factor 1 (season) and factor 2 (\% of $\mathrm{CBH})$.

For factor one (season), the best rate of bark recovery was found for the "spring" treatment for all years studied (Table I). The autumn and spring treatments were evaluated during the same period each year (in April), which resulted in a

TABLE I

ANOVA test results of percentage of bark recovery in Drimys brasiliensis, in 2005, 2006, 2007 and 2008, from experiment one.

\begin{tabular}{|c|c|c|c|c|c|}
\hline Sources of variation & $\mathrm{DF}$ & $\begin{array}{c}\text { MS } \\
2005\end{array}$ & $\begin{array}{c}\text { MS } \\
2006\end{array}$ & $\begin{array}{c}\text { MS } \\
2007\end{array}$ & $\begin{array}{c}\text { MS } \\
2008\end{array}$ \\
\hline Block & 5 & $0.04930 * *$ & $0.03202 * *$ & $0.03643 * *$ & $0.03728 * *$ \\
\hline Season (A) & 1 & $0.28214 * *$ & $0.07020 * *$ & $0.05048^{*}$ & $0.03757^{*}$ \\
\hline \% CBH (B) & 2 & $0.18861 * *$ & $0.14350 * *$ & $0.14635^{* *}$ & $0.12885^{* *}$ \\
\hline No. of strips (C) & 2 & $0.41722 * *$ & $0.32204 * *$ & $0.35796 * *$ & $0.38078 * *$ \\
\hline \multicolumn{6}{|l|}{ Interactions } \\
\hline $\mathrm{AB}$ & 2 & 0.01706 & 0.00522 & 0.00868 & 0.01016 \\
\hline $\mathrm{AC}$ & 2 & 0.00757 & 0.01915 & $0.03134 *$ & $0.04060 * *$ \\
\hline $\mathrm{BC}$ & 4 & 0.01176 & 0.00789 & 0.00455 & 0.00597 \\
\hline $\mathrm{ABC}$ & 4 & 0.00738 & 0.00939 & 0.00586 & 0.00272 \\
\hline Residual & 65 & 0.00696 & 0.00732 & 0.00778 & 0.00778 \\
\hline $\mathrm{CV}(\%)^{1}$ & & 26 & 20 & 16 & 14 \\
\hline Total & 87 & & & & \\
\hline
\end{tabular}

$\mathrm{DF}=$ degrees of freedom; MS = mean square; significance level $1 \% * *$ and $5 \% *$ of probability by the F-test. ${ }^{1}$ Experimental Variation Coefficient. 
6-month time advantage for recovery during the autumn season as compared to the spring season. Consequently, every year resulted in a higher average rate of bark regeneration.

The annual rates of bark recovery were defined by estimating regression equations, and were compared to the rates of bark regeneration for two seasons with the same regeneration time. The regeneration rates were found to be similar (Figure 1).

Autumn regeneration $=0.1853 \times$ time $\mathrm{R}^{2}=0.94$

Spring regeneration $=0.1855 \times$ time $\mathrm{R}^{2}=0.95$
Thus, there is no significant difference between seasons during all years of study, as well as no difference in the interaction between factor one, season of harvest, and factor two, the number of strips, for the years 2007 and 2008.

Delvaux et al. (2009), studying bark harvesting of 12 species in Benin (Africa), cited a general superiority in the recovery of plants harvested during spring in relation to plants harvested during autumn. However, when considering the individual species, they found that eight species regenerated better when harvested during spring, than when

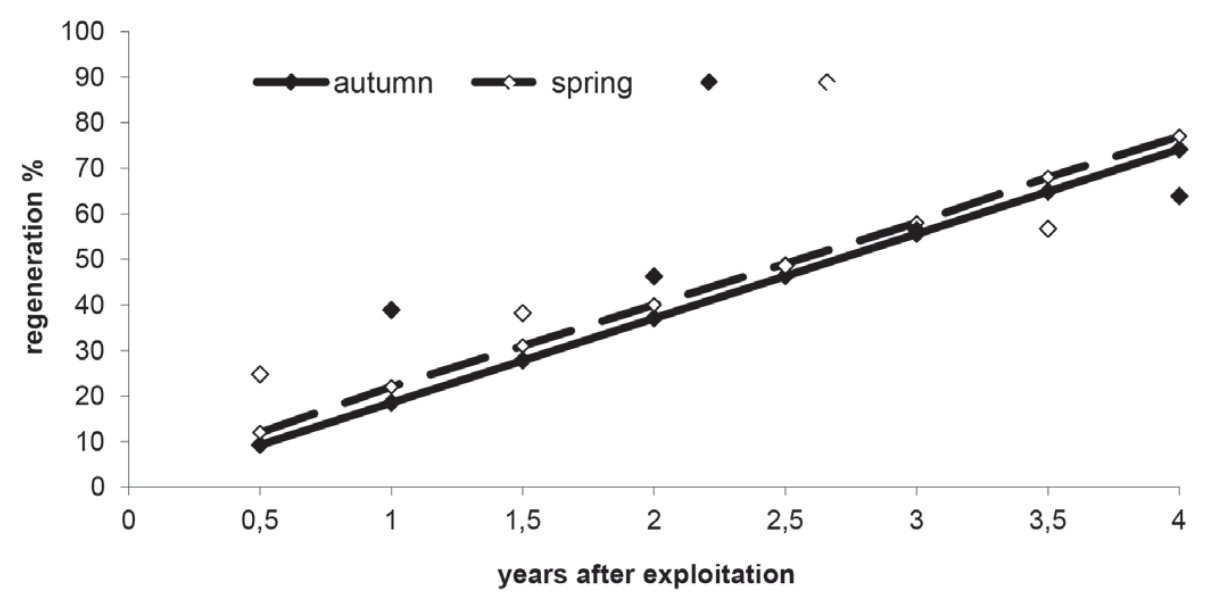

Figure 1 - Observed (dots) and estimated bark regeneration (lines) in Drimys brasiliensis in autumn and spring-time.

harvested during autumn, and three species showed no difference to the time of harvesting.

Although there are no differences between season of treatment, which indicates that $D$. brasiliensis can be exploited at any time, in the winter time the bark of the trunk does not come off as easily as in the autumn and spring time, which complicates the removal, and results in fragmented strips.

For factor two (percentage of $\mathrm{CBH}$ ) the best rates for bark regeneration were found to be for percentages of $20 \%$ to $30 \%$, where rates of recovery were intermediate, and the treatment of $40 \%$ had the lowest rate of bark regeneration for the years 2005 and 2006, which was found to be statistically significantly different (Table II). For the years 2007 and 2008 , treatments $20 \%$ and $30 \%$ were the best, with no statistically significant differences between them, and the treatment of $40 \%$ had lower rates of bark recovery (Table II).

\section{TABLE II}

Percentage of bark recovery in Drimys brasiliensis under different percentages of harvesting, in the years 2005 , 2006, 2007 and 2008, for experiment one.

\begin{tabular}{cllll}
\hline Percentage & \multicolumn{4}{c}{ Years } \\
\cline { 2 - 5 } of $\mathrm{CBH}^{1}$ & 2005 & 2006 & 2007 & 2008 \\
\hline 20 & $41 \mathbf{A}^{*}$ & $52 \mathbf{A}$ & $62 \mathbf{A}$ & $69 \mathbf{A}$ \\
30 & $32 \mathbf{B}$ & $42 \mathbf{B}$ & $54 \mathbf{A}$ & $63 \mathbf{A}$ \\
40 & $22 \mathbf{C}$ & $33 \mathbf{C}$ & $41 \mathbf{B}$ & $49 \mathbf{B}$ \\
\hline
\end{tabular}

${ }^{1}$ Circunference at breath height; *Numbers with same letter are not significantly different as per the Tukey test (0.05), comparison between treatments. 
Regardless of the $\mathrm{CBH}$ of the plant, the largest the harvested area was resulted in a larger wound which needed a longer time for bark recovery. The changes in recovery areas for different percentages of harvesting are shown in Figure 2.

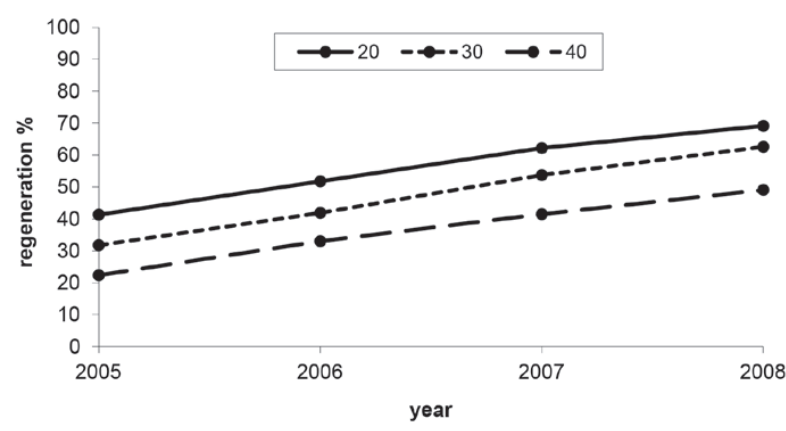

Figure 2 - Bark regeneration of Drimys brasiliensis under different percentages of exploitations (20, 30 and 40\%).

For factor three (number of strips), the highest rates of bark recovery were for the three-strip treatment. The two-strip treatment had intermediate rates of regeneration, and the one-strip treatment had the lowest rates of bark regeneration, for each year evaluated. The bark recovery for these treatments was found to be statistically different (Table III). Regardless of the plant's $\mathrm{CBH}$, the greater number of strips results in more narrow strips, facilitating the recovery of the wound area. The differences in the regenerated areas for different numbers of strips are shown in Figure 3.

TABLE III

Percentage of bark recovery in Drimys brasiliensis under different numbers of strips, in the years 2005, 2006, 2007 and 2008, for experiment one.

\begin{tabular}{ccccc}
\hline \multirow{2}{*}{$\begin{array}{c}\text { Number of } \\
\text { strips }\end{array}$} & $\mathbf{2 0 0 5}$ & $\mathbf{2 0 0 6}$ & $\mathbf{2 0 0 7}$ & $\mathbf{2 0 0 8}$ \\
\cline { 2 - 5 } & $18 \mathbf{C} *$ & $27 \mathbf{C}$ & $34 \mathbf{C}$ & $40 \mathbf{C}$ \\
1 & $35 \mathbf{B}$ & $47 \mathbf{B}$ & $58 \mathbf{B}$ & $66 \mathbf{B}$ \\
2 & $43 \mathbf{A}$ & $53 \mathbf{A}$ & $65 \mathbf{A}$ & $75 \mathbf{A}$ \\
\hline
\end{tabular}

*Numbers with same letter are not significantly different as per the Tukey test $(0.05)$, comparison between treatments.

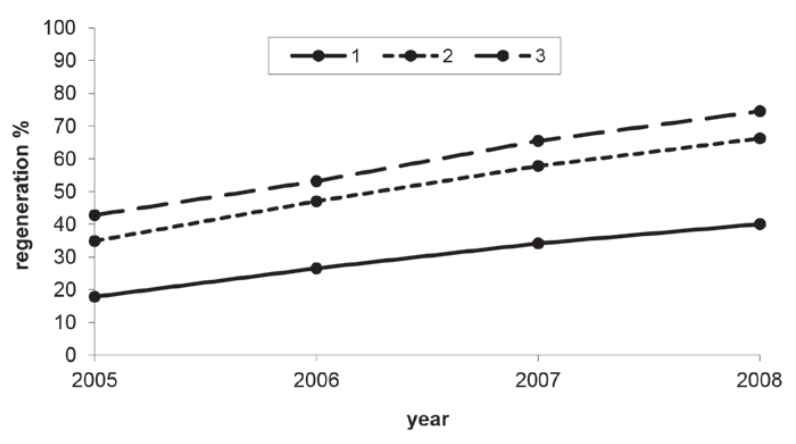

Figura 3 - Bark regeneration of Drimys brasiliensis under different amounts of exploited strips (1,2 and 3).

None of the treatments demonstrated complete bark recovery, however, individually, two plants showed complete bark recovery three years after harvesting (2007), which increased to six plants in the fourth year (2008) of the study.

Considering the percentage of the wound area in regards to insect and disease attacks (mainly fungi), no statistical differences were observed between factor one (season), and factor 3 (number of strips) (Table IV). For factor two (percentage of $\mathrm{CBH})$, the lowest incidences of insects and diseases were for treatments $20 \%$ and $30 \%$ which also had the highest rates of bark recovery. The treatment of $30 \%$ did not differ statistically from the treatment of $40 \%$ (Table IV).

\section{TABLE IV}

Percentage of insect (I) and disease (D) attacks from three sources of variation (season, percentage of $\mathrm{CBH}^{1}$ explored and number of strips) from experiment one, in the year 2008.

\begin{tabular}{ccc|ccc|ccc}
\hline Season & $\mathbf{I} \%$ & $\begin{array}{c}\text { D } \\
\text { \% }\end{array}$ & $\begin{array}{c}\text { \% } \\
\text { CBH }\end{array}$ & $\begin{array}{c}\text { I } \\
\text { \% }\end{array}$ & $\begin{array}{c}\text { D } \\
\text { \% }\end{array}$ & Strips & $\begin{array}{c}\text { I } \\
\text { \% }\end{array}$ & $\begin{array}{c}\text { D } \\
\text { \% }\end{array}$ \\
\hline \multirow{2}{*}{ Autumn } & 28 & 28 & $\mathbf{2 0}$ & 8 & 16 & $\mathbf{1}$ & 35 & 29 \\
& $\mathbf{A}$ & $\mathbf{A}$ & & $\mathbf{A}$ & $\mathbf{A}$ & & $\mathbf{A}$ & $\mathbf{A}$ \\
\multirow{4}{*}{ Spring } & 19 & 23 & & 25 & 30 & & 23 & 29 \\
& $\mathbf{A}$ & $\mathbf{A}$ & $\mathbf{3 0}$ & $\mathbf{A B}$ & $\mathbf{A B}$ & $\mathbf{2}$ & $\mathbf{A}$ & $\mathbf{A}$ \\
& & & & 38 & 31 & & 13 & 19 \\
& & & 40 & $\mathbf{B}$ & $\mathbf{B}$ & $\mathbf{3}$ & $\mathbf{A}$ & $\mathbf{A}$ \\
\hline
\end{tabular}

${ }^{1}$ Circunference at breast height; *Numbers with same letter are not significantly different as per the Dunn test (0.05), comparison done by column. 
The treatments used in experiment one resulted in a wide range of strip width, depending on tree diameter. For example, for a tree of $10 \mathrm{~cm}$ $\mathrm{CBH}$, a removal of $40 \%$ of $\mathrm{CBH}$ could result in a treatment of one strip of $4 \mathrm{~cm}$, while with a $90 \mathrm{~cm}$ CBH tree, a removal of $20 \%$ could entail three strips of $6 \mathrm{~cm}$. Greater CBHs result in wider strips, therefore wide strips are exploited, even within the same percentage of harvesting. The same goes for the number of strips: more strips result in a smaller width, facilitating the recovery of the wound area. A trend was observed, regardless of the treatment applied: narrow strips regenerated more rapidly than wider strips, as can be seen in Figure 4.

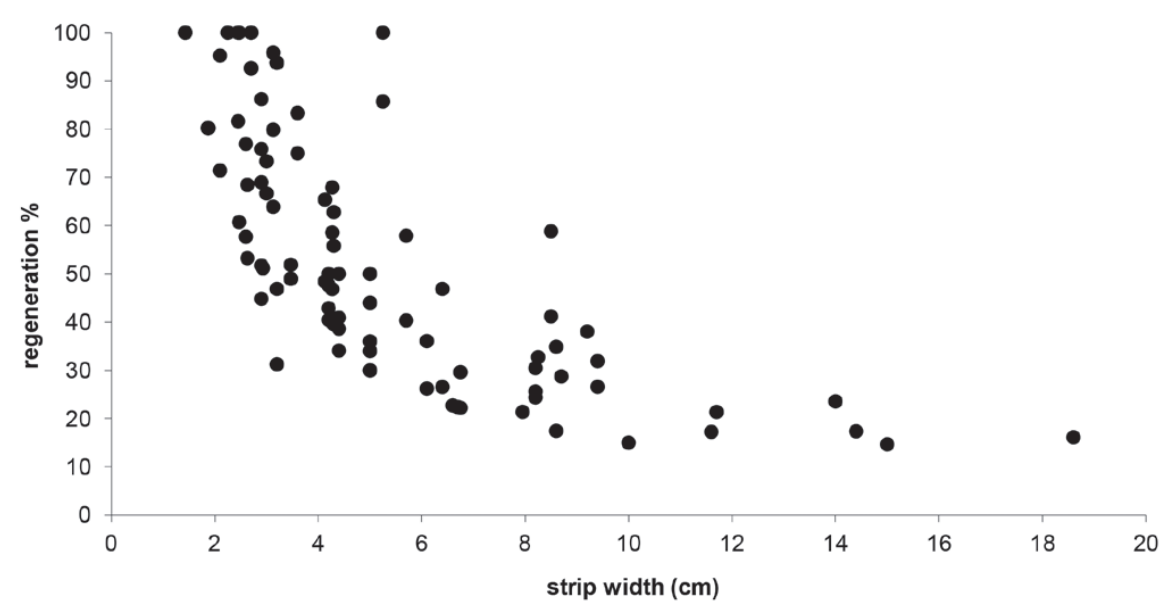

Figure 4 - Percentage of bark recovery in Drimys brasiliensis from different exploited strip width after one year following harvesting.

Most of the bark regrowth comes from living tissue (vascular cambium, phloem, feloderm and phellogen) along the edge of the exploited area towards its center. To a lesser extent, but mostly non-existent, the bark recovery comes from the remaining living cells on the xylem in the sheet of the exploited area at the time of bark harvesting.

It is from these living cells that the plant will heal the wound area. The wound area will heal through the formation of all living tissues already mentioned, along with the cork and the outer layer of skin, which is formed by dead cells originating from the phellogen.

The harvesting of two strips $2 \mathrm{~cm}$ wide and 1 meter in length each (total perimeter $=4.08 \mathrm{~m}$ ) is preferred to a strip $4 \mathrm{~cm}$ wide and 1 meter in length (total perimeter $=2.08 \mathrm{~m}$ ). Although the bark production is the same in both cases, the first case with two strips allows for the greater edge to accelerate the regeneration of the harvested bark. The same pattern was observed with respect to attack by insects and diseases: narrow strips resulted in a lower incidence due to smaller exposed areas (Figure 5). The main pests were termites and the main diseases were fungi. Nkeng et al. (2010) found that $94 \%$ of exploited Prunus africana trees were attacked by insects in Cameroon. Chungu et al. (2007) also found that the wood of medicinal trees in Zambia were severely deteriorated after debarking, displaying extensive tissue discoloration, increased insect infestation and profuse gum exudation. However, they found that covering the wound site with mud considerably protected the trees from wood deterioration and insect damage and this constitutes the best and most sustainable bark harvesting prescription for biodiversity conservation.

Geldenhuys et al. (2007), testing the bark harvesting for 22 native species occurring in southern Africa, also found that in general, the 


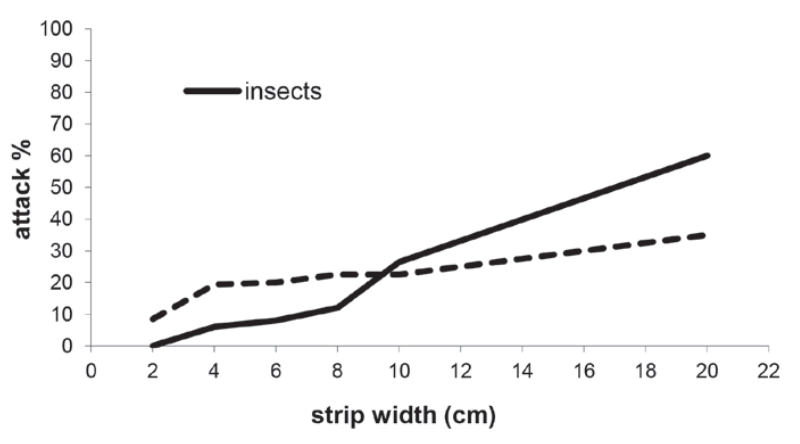

Figure 5 - Percentage of insect and disease attacks in Drimys brasiliensis measured on different widths of strips.

smaller the wounds, the higher the rates of bark recovery, indicating widths smaller than $10 \mathrm{~cm}$ were the best option. Geldenhuys and Mitchell (2006) also indicated the harvesting of strips less than 10 cm wide were the best option. Delvaux et al. (2009) found that out of 12 species studied for the intensity of bark harvesting, eight showed significant differences among the seven treatments used, and four species were indifferent to these treatments.

In Cameroon, the Forestry Administration indicated the following for the sustainable harvesting of medicinal bark in general: a) only trees with diameter at breast height $(\mathrm{DBH})>30 \mathrm{~cm}$ can be debarked; b) trees with $\mathrm{DBH}<50 \mathrm{~cm}$ should be debarked with two strips on opposite sides, each strip no wider than $1 / 4$ of the circumference of the tree $(50 \%)$; c) trees with DBH $50 \mathrm{~cm}$ should be debarked in 4 strips regularly distributed around the circumference, each no wider than $1 / 8$ of the circumference $(50 \%)$; d) lateral roots with a minimum diameter of $20 \mathrm{~cm}$ of trees with $\mathrm{DBH} \geq 50 \mathrm{~cm}$ can also be debarked (Ndibi and Kay 1997). However, Nkeng et al. (2010) found that harvesting was sustainable in only $9 \%$ of the 710 trees in 14 study sites. Disorderly harvesting was also found for Stryphnodendron adstringens in Brazil (Borges Filho and Felfili 2003). Similar methodology was proposed by Minore and Weatherly (1994), indicating that partial bark removal from one side of the tree will probably not seriously affect the growth of Taxus brevifolia if less than $50 \%$ of the bark is removed.
With regard to phenological pattern and the increments in DBH and total height (Mariot 2010), in the four years studied, none of the treatments differed significantly from the control, meaning that the harvesting of bark did not modify the growth of the species nor the rate of reproduction in any conditions studied.

This nondestructive method of obtaining this non-timber forest product, by the harvest of bark strips, does not eliminate the genotype of the population or reduce their reproductive success, and allows periodic cycles of harvesting of the same plant. Thus, the plant may continue to contribute their alleles through pollen and seeds to maintain the population dynamics of species, since the results showed that the harvesting systems tested did not interfere in the growth and reproductive biology of D. brasiliensis during the evaluation period.

From the results of Experiment One, a harvest of $20 \%$ or $30 \%$ of $\mathrm{CBH}$, in three strips, is recommended for $D$. brasiliensis.

When drying the harvested bark, it was found that the dried bark has income of $41 \%$ compared to the fresh weight (dry weight $=$ wet weight $\mathrm{x}$ $\left.0.41 * *, \mathrm{R}^{2}=0.99\right)$.

\section{EXPERIMENT 2}

From the results of Experiment One, which indicated that bark regenerated better with narrow-strip harvests, experiment two was installed, where the width of the strip was fixed at $2 \mathrm{~cm}$, varying the distance between strips ( 4 and $8 \mathrm{~cm}$ - factor one) and length of strips ( 1 and $2 \mathrm{~m}$ - factor two).

ANOVA test results for experiment two, for all years evaluated, is presented in Table V. The means for bark recovery for each combination of factors is presented in Table VI. No significant differences was found between the levels of two factors analyzed individually for all years, or their interactions, regardless of the length of the strip and the distance between them, proving that the main factor for rapid bark recovery in $D$. brasiliensis is the width of the strip. 
TABLE V

ANOVA test results for percentage of bark recovery in Drimys brasiliensis, in the years 2005, 2006, 2007 and 2008, from experiment two.

\begin{tabular}{|c|c|c|c|c|c|}
\hline Sources of variation & $\mathrm{DF}$ & MS 2005 & MS 2006 & MS 2007 & MS 2008 \\
\hline Block & 3 & $0.05526^{1}$ & 0.06048 & 0.04714 & 0.03937 \\
\hline Distance between strips (A) & 1 & 0.00262 & 0.00236 & 0.01810 & 0.04030 \\
\hline Length of strip (B) & 1 & 0.00001 & 0.00020 & 0.00262 & 0.00213 \\
\hline \multicolumn{6}{|l|}{ Interactions } \\
\hline $\mathrm{AB}$ & 1 & 0.01534 & 0.03350 & 0.01888 & 0.00603 \\
\hline $\begin{array}{l}\text { Residual } \\
\text { CV }(\%)^{2}\end{array}$ & 7 & $\begin{array}{c}0.05391 \\
34\end{array}$ & $\begin{array}{c}0.06917 \\
35\end{array}$ & $\begin{array}{c}0.06256 \\
29\end{array}$ & $\begin{array}{c}0.04516 \\
23\end{array}$ \\
\hline Total & 13 & & & & \\
\hline
\end{tabular}

${ }^{1}$ level $1 \% * *$ and $5 \% *$ of probability as per the F-test; ${ }^{2}$ Experimental Variation Coefficient.

TABLE VI

Percentage of bark recovery in Drimys brasiliensis, from experiment two.

\begin{tabular}{c|c|cccc}
\hline \multicolumn{2}{c|}{ Source of Variation } & \multicolumn{4}{|c}{ Year } \\
\hline $\begin{array}{c}\text { Distance } \\
\text { between } \\
\text { strips (cm) }\end{array}$ & $\begin{array}{c}\text { Length of } \\
\text { strip (m) }\end{array}$ & $\mathbf{2 0 0 5}$ & $\mathbf{2 0 0 6}$ & $\mathbf{2 0 0 7}$ & $\mathbf{2 0 0 8}$ \\
\hline 4 & 1 & $47 \mathrm{~A}$ & $59 \mathrm{~A}$ & $80 \mathrm{~A}$ & $88 \mathrm{~A}$ \\
4 & 2 & $46 \mathrm{~A}$ & $68 \mathrm{~A}$ & $80 \mathrm{~A}$ & $90 \mathrm{~A}$ \\
8 & 1 & $48 \mathrm{~A}$ & $67 \mathrm{~A}$ & $70 \mathrm{~A}$ & $77 \mathrm{~A}$ \\
8 & 2 & $50 \mathrm{~A}$ & $67 \mathrm{~A}$ & $76 \mathrm{~A}$ & $80 \mathrm{~A}$ \\
\hline
\end{tabular}

*Numbers with same letter are not significantly different as per the Dunn test (0.05), comparison done by column.

Narrow strips regenerate faster than wider strips, mainly due to higher contribution from the edges of the living tissues of the exploited strips than by contribution of living tissue from the wound surface.

Regarding the attack of insects and diseases, the result of experiment two was $0 \%$ for all treatments, confirming the results of experiment one, where $2 \mathrm{~cm}$ strips, regardless of treatment, were not attacked by insects and showed a very low incidence of diseases $(8.5 \%)$.

All plants used in experiment two are located in the FF, an area used for cattle production, with regular mowing, and higher incidence of sunlight and ventilation as compared to the CNF. These factors possibly reduce the humidity of the environment, discouraging the attack of pathogens in the FF. In the case of experiment one, the plants from the two repetitions of FF had a lower incidence of insects and diseases than plants from the four repetitions of the CNF, corroborating with this hypothesis.

Therefore, considering the data from experiment two, supplementing the information obtained in experiment one, the main factor for efficient recovery of exploited strips in D. brasiliensis is the width of the strip, which should be as narrow as $2 \mathrm{~cm}$, regardless of the strip length and distance between them. This implies strips $2 \mathrm{~cm}$ wide and 2 meters high, spaced $4 \mathrm{~cm}$ apart.

Considering all treatments, none of the treatments resulted in complete plant recovery. However, individually, some plants $(21 \%$ - 2007) regenerated the total exploited area three years after harvesting, and this value increased $42 \%$ in the fourth year of the study (2008).

In the fifth year after harvesting these values will probably increase, since the regenerated plants that have not yet closed the exploited area are very close to full regeneration. Therefore a harvesting cycle of 5 years is proposed, however some plants will be available for a new harvest after the third year.

The regenerating values from experiment two are much higher than those found in experiment one, because all the strips were narrow $(2 \mathrm{~cm})$, demonstrating that for $D$. brasiliensis the determining factor for bark regrowth after harvesting is the width of the strip. 


\section{BARK PRODUCTION}

Using data from Mariot et al. (2010) (Figure 6) we calculated the bark production of $D$. brasiliensis per hectare in the CNF and in the FGPC. A regression equation based on the results of the experiments of bark production was estimated, considering the increased thickness of the bark due to the increase of the plant's DBH. The following equation was used: $\operatorname{DRYWEIGHT}(\mathrm{g})=3.39 * * \times \mathrm{DBH}(\mathrm{cm})\left(\mathrm{R}^{2}=0.96\right)$. From this equation, and considering the increasing number of strips with the increasing plant $\mathrm{DBH}$, it was estimated that productivity in the FGPC studied by Mariot et al. (2010) (31 plants with $\mathrm{DBH}>5 \mathrm{~cm}$ per hectare), and the CNF (105 plants with $\mathrm{DBH}>$ $5 \mathrm{~cm}$ per hectare), is respectively 35.5 and $38.5 \mathrm{~kg}$ of dried bark per hectare for a five year cycle.

Despite a greater number of plants in the CNF and higher stem density in relation to the RGFC, productivity did not increase in the same proportion in $\mathrm{CNF}$ because the plants have a smaller DBH
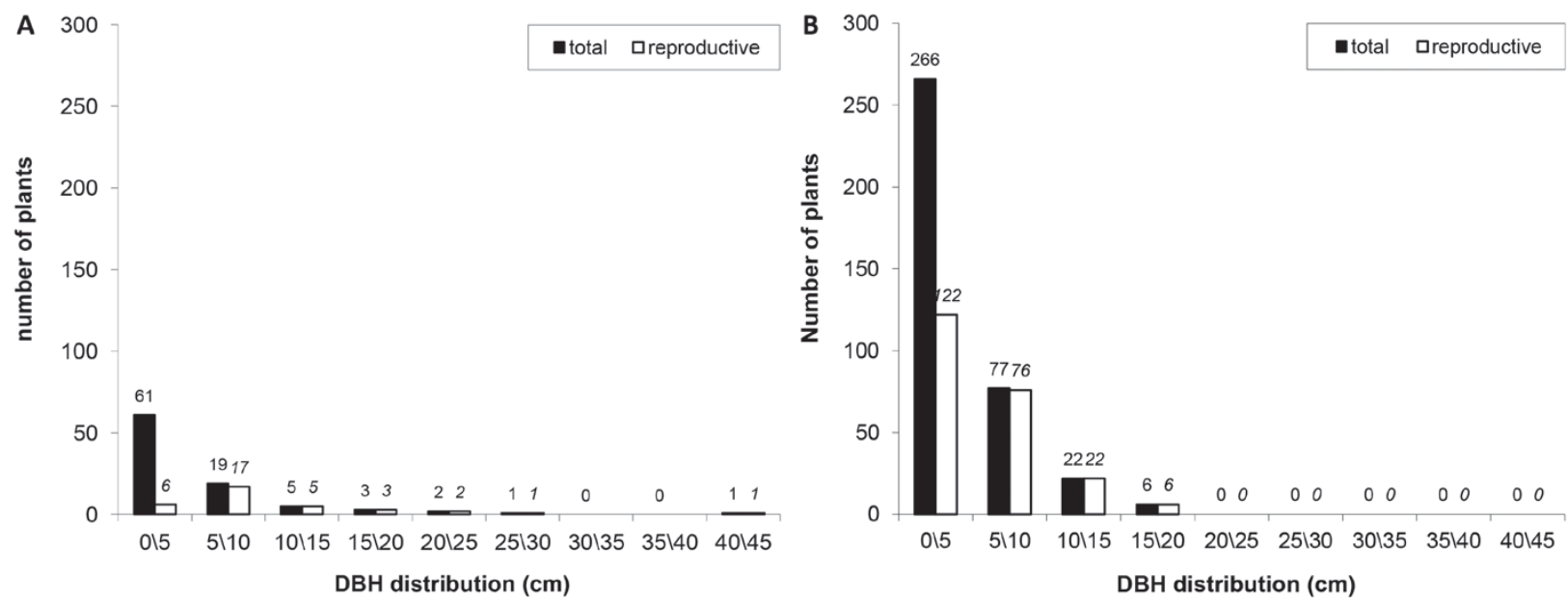

Figure 6 - Diametric distribution of Drimys brasilienis in the Forest Genetic Park of Caçador (A) and Caçador National Forest (B), according to Mariot et al. (2010).

(average of $8.3 \mathrm{~cm}$ for plants with $\mathrm{DBH}>5 \mathrm{~cm}$, and average of $11.2 \mathrm{~cm}$ for plants with $\mathrm{DBH}>5 \mathrm{~cm}$ in FGPC), reflecting lower productivity per plant.

However, overall productivity was higher in the CNF compared with the FGPC, reflecting the potential of secondary forest areas in the management of this species. It is important to note that secondary forests cover most of the remaining Atlantic Forest.

Considering the studied aspects, we find that there is potential for the sustainable management of $D$. brasiliensis with the possibility of financial gain from the harvesting of natural populations. $D$. brasiliensis is only one of the products that can be obtained from the forest as a source of supplementary income, encouraging the conservation of remaining fragments of the Atlantic Rainforest.
Apart from medicinal bark, there is a high diversity of other non-timber forest products that could be harvested from these areas, including other medicinal plants (Maytenus ilicifolia - Steenbock et al. 2003, Steenbock and Reis 2004, and Bromelia antiacantha-Duarte etal.2007, Filippon etal. in press), edible products (Araucaria angustifolia seeds - Silva and Reis 2009) and ornamental plants (bromeliads and orchids), as well as woody products as sources of energy (firewood and charcoal) and raw material for construction (Mimosa scabrella - Steenbock et al. 2011). The combination of harvesting of these various products could enhance the conservation of tropical or subtropical forests in the world. Only with financial gains by the property owners will most of the remaining forest be conserved through use. 


\section{ACKNOWLEDGMENTS}

This research was supported by Coordenação de Aperfeiçoamento de Pessoal de Nível Superior (CAPES) and Conselho Nacional de Desenvolvimento Científico e Tecnológico (CNPq). We are grateful to Instituto Brasileiro do Meio Ambiente e dos Recursos Naturais Renováveis (IBAMA), Instituto Chico Mendes de Conservação da Biodiversidade (ICMBio), Empresa de Pesquisa Agropecuária e Extensão Rural de Santa Catarina (EPAGRI) and the owners of the small farmers Josué Dalasanta and Alcebíades for their assistance with data collection in the field.

\section{RESUMO}

Drimys brasiliensis Miers, popularmente conhecida como cataia ou casca-de-anta, é uma árvore nativa da Mata Atlântica, e suas cascas são usadas medicinalmente, através da exploração de populações naturais. Este estudo examinou a capacidade de reposição de cascas de $D$. brasiliensis sob diferentes metodologias de coleta de cascas, assim como a influências desses métodos na sua dinâmica populacional e biologia reprodutiva. Apesar de nenhum dos tratamentos terem resultado em modificações nas taxas de incremento em diâmetro à altura do peito e altura, nem do comportamento fenológico, quanto mais larga a lasca das cascas exploradas, menores as taxas de regeneração e maiores os índices de ataque de pragas e doenças. Portanto, é indicado que as lascas tenham largura de $2 \mathrm{~cm}$ por $2 \mathrm{~m}$ de altura, distanciadas entre si $4 \mathrm{~cm}$. A partir desses estudos, D. brasiliensis tem um alto potencial de manejo sustentado em suas populacões naturais, demonstrando a possibilidade de gerar uma renda para proprietários rurais e contribuir para o uso e a conservação da Mata Atlântica.

Palavras-chave: colheita de casca, planta medicinal, manejo sustentável, drimys brasiliensis, ataque de insetos.

\section{REFERENCES}

BALDAUF C, HANAZAKI N AND REIS MS. 2007. Caracterização etnobotância dos sistemas de manejo de samambaiapreta (Rumohra adiantiformis (G. Forst) Ching Dryopteridaceae) utilizados no sul do Brasil. Acta Bot Bras 21(4): 823-834.
BALDAUF C AND REIS MS. 2010. Effects of harvesting on population structure of leatherleaf fern (Rumohra adiantiformis (G. Forst.) Ching) in Brazilian Atlantic Rainforest. Amer Fern J 100: 148-158.

BoRGES FILHO HC AND FELFILI JM. 2003. Avaliação dos níveis de extrativismo da casca de barbatimão [Stryphnodendron adstringens (Mart.) Coville] no Distrito Federal, Brasil. R Árvore 27(5): 735-745.

Cechinel-Filho V, Schlemper V, SANTOS ARS, Pinheiro TR, YunEs RA, MENDES GL, CALIXTO JB AND MONACHE FD. 1998. Isolation and identification of active compounds from Drimys winteri barks. J Ethnoph 62: 223-227.

Chungu A, Kankolongo M, Roux J and Malambo FM. 2007. Bark removal for medicinal use predisposes indigenous forest trees to wood degradation in Zambia. Southern Hemisphere For J 69(3): 157-163.

CONTE R, ReIS MS, MANTOVANI A AND VENCOVSKY R. 2008. Genetic structure and mating system of Euterpe edulis Mart. Populations: a comparative analysis using microsatellite and allozyme markers. J Heredity 99(5): 476-482.

CUnNINGHAM AB. 2001. Applied Ethnobotany: people, wild plant use \& conservation. People and Plants Conservation Manuals. London and Sterling: WWF, UNESO, Royal Botanic Garden.

Cunningham AB AND MBenkim FT. 1993. Sustainability of harvesting Prunus Africana bark in Cameroon: a medicinal plant in international trade. People and Plants Working Paper. Paris: UNESCO.

Delvaux C, Sinsin B, Darchamberau F and VAN Damme P. 2009. Recovery from bark harvesting of 12 medicinal trees species in Benin, West Africa. J Appl Ecol 46(3): 703-712.

Duarte AS, Silva CV, Puchalski A, Mantovani M, Silva JZ AND REIS MS. 2007. Estrutura demográfica e produção de frutos de Bromelia antiacantha Bertol. R Bras Plantas Med 9(3):106-112.

FANTINI AC, REIS A, REIS MS AND GUERRA MP. 1992. Sustained yield management in tropical forest: a proposal based on the autoecology of species. Sellowia 42/44: 25-33.

FILIPPON S, FERNANDES CD AND REIS MS. IN PRESS. Produção de frutos para uso medicinal em Bromelia antiancatha (caraguatá): fundamentos para um extrastivismo sustentável. R Bras Plantas Med.

FOURNIER LA. 1974. Un método cuantitativo para la medición de características fenológicas en árboles. Turrialba 24: 422-423.

Geldenhuys CJ AND Mitchell D. 2006. Sustainable harvesting technologies. In: Diederichs N, Comercialising Medicina Plants: A Southern African Guide. Stellenbosh: Sun Press, p. 21-39.

Geldenhuys CJ, Syampungani S, MeKe G ANd Vermeulen WJ. 2007. Response of different species on bark harvesting for traditional medicine in Southern Africa. In: BESTER JJ, SEYDACK AHW, VORSTER T, VAN DER MERWE IJ and DZIVHANI S (Eds), Multiple use management of natural forests and woodlands: policy refinements and scientific progress. Pretoria: Dep. Water Affairs For, p. 55-62. 
GUEDJE NM, ZUIDEMA PA, DURING H, FOAHOM B AND LEJOLY J. 2007. Tree bark as a non-timber forest product: The effect of bark collection on population structure and dynamics of Garcinia lucida Vesque. F Ecol Manag 240: 1-12.

HALl P AND BAWA K. 1993. Methods to asses the impact of extraction of non-timber tropical forest products on plant populations. Econ Bot 47: 234-247.

Malheiros A, Cechinel-Filho V, Schmitt CB, Yunes RA, Escalante A, SvetaZ L, ZACCHINO S AND MONACHE FD. 2005. Antifungal activity of drimane sesquiterpenes from Drimys brasiliensis using bioassay-guided fractionation. J Pharm \& Pharm Sci 8(2): 335-339.

MARIOT A, Di StAsi LC AND REIS MS. 2002. Genetic Diversity in Natural Populations of Piper cernuum. J Heredity 93(5): 61-65.

Mariot A, MANTOVANi A, BITTENCOURT R, FERREIRA DK AND REIS MS. 2010. Estrutura populacional e incremento corrente anual de casca-de-anta (Drimys brasiliensis Miers - Winteraceae) em Caçador, Santa Catarina, Brasil. R Bras Plantas Med 12(2): 168-178.

MARIOT A, MANTOVANi A AND ReIS MS. 2003. Uso e conservação de Piper cernuum Vell. (Piperaceae) na Mata Atlântica: I. Fenologia reprodutiva e dispersão de sementes. R Bras Plantas Med 5(2): 1-10.

MARiot A, OdorizZI J, NAScimento JV AND ReIS MS. 2007. Uso e conservação de Piper cernuum Vell. (Piperaceae) na Mata Atlântica: II. Estrutura demográfica e potencial de manejo em floresta primária e secundária. R Bras Plantas Med 9(1): 13-20.

MARIOT A AND REIS MS. 2006. Biodiversidade e sua importância como fonte de plantas medicinais. R Ciênc Agrovet 5: 53-61.

MinORE D AND WEATHERLY HG. 1994. Effects of partial bark removal on the growth of Pacific yew. J For Res 24(4): 860-862.

NDIBI BP AND KAY EJ. 1997. The regulatory framework of medicinal plants in Cameroon; the case of Prunus africana on Mount Cameroon. Biodivers Conserv 6: 1409-1412.

NKENG PF, INGRAM V AND AwONO A. 2010. Assessment of Prunus africana bark exploitation methods and sustainable exploitation in the South west, North-West and Adamaoua regions of Cameroon. CIFOR, $50 \mathrm{p}$.

REIS MS. 1996. Manejo sustentado de plantas medicinais em ecossistemas tropicais. In: DI STASI LC, Plantas Medicinais: arte e ciência. Um guia de estudo interdisciplinar. São Paulo: UNESP, p. 199-215.

REIS MS, FANTINI AC, NODARI RO, REIS A, GUERRA MP AND MANTOVANI A. 2000a. Management and conservation of natural populations in Atlantic rain Forest: the case study of plam heart (Euterpe edulis Martius). Biotropica (32): 894-902.

ReIS MS, MARIOT A And SteEnBock W. 2003. Diversidade e domesticação de plantas medicinais. In: SIMÕES C ET AL. (Eds), Farmacognosia: da planta ao medicamento. Porto Alegre/ Florianópolis: Editora da UFRGS/ Editora da UFSC, p. 45-74.
REIS MS, NODARI RO, GUERRA MP, FANTINI AC AND REIS A 2000b. Sustainable yild management of Euterpe edulis Martius (Palmae): a tropical palm tree from the Atlantic Tropical Forest - Brasil. J Sus For 11: 1-17.

Ribeiro Vls, Rolim V, Bordignon S, Henriques AT, DORNeles GG, Limberger RP AND VON POSER G. 2008. Chemical composition and larvicidal properties of the essential oils from Drimys brasiliensis Miers (Winteraceae) on the cattle tick Rhipicephalus (Boophilus) microplus and the brown dog tick Rhipicephalus sanguineus. Paras Res 102: 531-535.

Shanley P, PIERCE A AND LAIRD S. 2006. Além da Madeira: certificação de produtos florestais não-madeireiros. Bogor, Indonésia: Centro de Pesquisa Florestal Internacional (CIFOR).

SiLva C AND REIS MS. 2009. Produção de pinhão na região de Caçador SC: Aspectos da obtenção e sua importância para comunidades locais. Ciên Flor 19: 365-376.

SILVA JZ AND REIS MS. 2010. Effects of different simulated management intensities on the genetic diversity of a heartof-palm tree natural population (Euterpe edulis Martius). Sil Gen 59: 201-210.

SteEnbock W, Radomski Mi, SoAres AO, Puchalski A, GOMES GS AND REIS MS. 2003. Avaliação de características fenotípicas para a determinação do rendimento foliar em espinheira-santa (Maytenus ilicifolia Martius). R Bras Plantas Med 6(1): 71-76.

STEENBOCK W AND REIS MS. 2004. Manejo de populações naturais de espinheira-santa. In: Reis MS and Silva SR, Conservação e uso sustentável de plantas medicinais e aromáticas: espinheira-santa. Brasília: Ibam, p. 145-161.

SteEnBock W, Siminski A, FANTINI AC AND REIS MS. 2011. Ocorrência da bracatinga (Mimosa scabrella Benth.) em bracatingais manejados e em florestas secundárias na região do planalto catarinense. R Árv 35: 845-857.

TICKTIN T. 2004. The ecological implications of harvesting non-timber forest products. J Appl Ecol 41: 11-21.

TRINTA EF AND SANTOS E. 1997. Flora Ilustrada Catarinense: Winteráceas. Itajaí, Herbário Barbosa Rodrigues.

VERMEULEN WJ. 2007. Sustainable bark harvesting for medicinal use: matching species to prescriptions. In: BESTER JJ, SEYDACK AHW, VORSTER T, VAN DER MERWE IJ and DZIVHANI S (Eds), Multiple use management of natural forests and woodlands: policy refinements and scientific progress. Pretoria: Dep. Water Affairs For, p. 82-89.

ZAR JH. 1999. Biostatistical Analysis. Fourth Edition. Prentice Hall, Inc. New Jersey. 